\title{
$1 \quad$ Nighttime air quality under desert conditions
}

2 Wendy S. Goliff ${ }^{1}$, Menachem Luria ${ }^{2}$, Donald R. Blake ${ }^{3}$, Barbara Zielinska ${ }^{4}$, Gannet Hallar ${ }^{4}$, Ralph J.

3 Valente $^{5}$, Charlene V. Lawson ${ }^{6,7}$, William R. Stockwell ${ }^{4,6}$

$4 \quad{ }^{1}$ College of Engineering Center for Environmental Research and Technology University of California, 5 Riverside

$6 \quad{ }^{2}$ The Hebrew University in Jerusalem, Earth Science Institute

$7 \quad{ }^{3}$ Department of Chemistry, University of California, Irvine

$8 \quad{ }^{4}$ Division of Atmospheric Sciences, Desert Research Institute, Reno, Nevada

$9 \quad{ }^{5}$ Environmental Technologies Department, Tennessee Valley Authority, Muscle Shoals, Alabama, USA.

$10{ }^{6}$ Howard University, Department of Chemistry, Washington, DC

$11 \quad{ }^{7}$ Environmental Sciences, Shell Global Solutions (US), Houston, Texas

Corresponding Author: Wendy S. Goliff, College of Engineering Center for Environmental Research and Technology University of California, Riverside, 1084 Columbia Avenue, Riverside, CA 92507, phone: 951 781-5665; fax: 951-781-5790; email: wendyg@ cert.ucr.edu

Key words: Nighttime chemistry; nitrate radical; free troposphere; 0-D modeling; tropospheric measurements 
Nighttime concentrations of the gas phase nitrate radical $\left(\mathrm{NO}_{3}\right)$ were successfully measured during a four week field campaign in an arid urban location, Reno Nevada, using long-path Differential Optical Absorbance Spectrometry (DOAS). While typical concentrations of $\mathrm{NO}_{3}$ ranged from 5 to $20 \mathrm{ppt}$, elevated concentrations were observed during a wildfire event. Horizontal mixing in the free troposphere was considerable because the sampling site was above the stable nocturnal boundary layer every night and this justified a box modeling approach. Process analysis of box model simulations showed $\mathrm{NO}_{3}$ accounted for approximately half of the loss of internal olefins, $60 \%$ of the isoprene loss, and $85 \%$ of the $\alpha$-pinene loss during the nighttime hours during a typical night of the field study. $\mathrm{The}^{\mathrm{NO}} \mathrm{N}_{3}+$ aldehyde reactions were not as important as anticipated. On a polluted night impacted by wildfires upwind of the sampling location, $\mathrm{NO}_{3}$ reactions were more important. Model simulations overpredicted $\mathrm{NO}_{2}$ concentrations for both case studies and inorganic chemistry was the biggest influence on $\mathrm{NO}_{3}$ concentrations and on nitric acid formation. The overprediction may be due to additional $\mathrm{NO}_{2}$ loss processes that were not included in the box model, as deposition and $\mathrm{N}_{2} \mathrm{O}_{5}$ uptake had no significant effect on $\mathrm{NO}_{2}$ levels.

\section{Introduction}

Nitrogen oxides $\left(\mathrm{NO}_{\mathrm{x}}=\right.$ nitric oxide $(\mathrm{NO})+$ nitrogen dioxide $\left.\left(\mathrm{NO}_{2}\right)\right)$ are important precursors for the formation of tropospheric ozone and nitrate containing aerosols (Frost et al. 2006; Ng et al. 2007). These are produced through a highly non-linear mechanism involving nitrogen oxides and volatile organic compounds (VOC).

Multi-day regional scale modeling studies were among the first to show that nighttime losses of $\mathrm{NO}_{\mathrm{x}}$ could affect ozone formation on subsequent days (e.g., Dimitroulopoulou and Marsh 1997). Many of the known nighttime loss mechanisms for $\mathrm{NO}_{\mathrm{x}}$ involve the formation of the nitrate radical $\left(\mathrm{NO}_{3}\right)$.

Nitrate radical is formed in the troposphere by the reaction of $\mathrm{NO}_{2}$ with $\mathrm{O}_{3}$ (Atkinson et al. 2006).

$\mathrm{NO}_{2}+\mathrm{O}_{3} \rightarrow \mathrm{NO}_{3}+\mathrm{O}_{2} ; \mathrm{k}_{1}(298 \mathrm{~K})=3.5 \times 10^{-17} \mathrm{~cm}^{3} \mathrm{~s}^{-1}$

The formation of $\mathrm{NO}_{3}$ results in only small $\mathrm{NO}_{\mathrm{x}}$ losses during the day because $\mathrm{NO}_{3}$ rapidly photolyzes to regenerate $\mathrm{NO}$ and $\mathrm{NO}_{2}$ under unobstructed clear sky conditions. The concentration of $\mathrm{NO}_{3}$ is very low

$\mathrm{NO}_{3}+\mathrm{NO} \rightarrow 2 \mathrm{NO}_{2}$

$\mathrm{NO}_{3}$ may also undergo thermal decomposition:

$\mathrm{NO}_{3}+\mathrm{M} \rightarrow \mathrm{NO}+\mathrm{O}_{2}+\mathrm{M}$

However, this reaction is slow $\left(2.5 \times 10^{6} \exp \left(-6.1 \times 10^{3} / \mathrm{T}\right) \mathrm{s}^{-1}\right.$; Johnston et al. 1986).

During the nighttime in regions with low $\mathrm{NO}$ concentrations $\mathrm{NO}_{3}$ reacts with a number of $\mathrm{VOC}$ to produce nitric acid $\left(\mathrm{HNO}_{3}\right)$ that in the presence of gas-phase ammonia $\left(\mathrm{NH}_{3}\right)$ can react to produce ammonium nitrate $\left(\mathrm{NH}_{4} \mathrm{NO}_{3}\right)$. Under the proper conditions of humidity and temperature $\mathrm{NH}_{4} \mathrm{NO}_{3}$ will 
saturated hydrocarbons to form $\mathrm{HNO}_{3}$ but these reactions are slow, on the order of $10^{-17} \mathrm{~cm}^{3}$ molecule $\mathrm{s}^{-1}$. More important in the polluted atmosphere is the reaction of $\mathrm{NO}_{3}$ with aldehydes to form $\mathrm{HNO}_{3}$, hydroperoxy radical $\left(\mathrm{HO}_{2}\right)$ and organic peroxy radicals $\left(\mathrm{RO}_{2}\right)$ (Stockwell and Calvert 1983; Cantrell et al. 1985). $\mathrm{NO}_{3}$ reacts with alkenes by its addition to double bonds with $\mathrm{k}_{298}$ in the range of $10^{-16}$ to $10^{-11} \mathrm{~cm}^{3}$ molecule $\mathrm{s}^{-1}$ ). The nighttime reactions of $\mathrm{NO}_{3}$ with alkenes can be a loss mechanism for alkenes that is as important as their daytime reactions with HO (Geyer et al. 2003; Brown et al. 2011).

Important indirect sinks for $\mathrm{NO}_{3}$ involve the formation of dinitrogen pentoxide $\left(\mathrm{N}_{2} \mathrm{O}_{5}\right)$.

$\mathrm{NO}_{2}+\mathrm{NO}_{3}+\mathrm{M} \leftrightarrow \mathrm{N}_{2} \mathrm{O}_{5}+\mathrm{M}$

Although Reaction 5 is slow in the gas phase due to entropy considerations (Calvert and Stockwell 1983, Wahner et al. 1998):

$\mathrm{N}_{2} \mathrm{O}_{5}(\mathrm{~g})+\mathrm{H}_{2} \mathrm{O}(\mathrm{g}) \rightarrow 2 \mathrm{HNO}_{3}(\mathrm{~g})$

Reaction 6 is fast on aerosols coated with liquid water (Chang et al. 2011).

$\mathrm{N}_{2} \mathrm{O}_{5}(\mathrm{~g})+\mathrm{H}_{2} \mathrm{O}(\mathrm{aq}) \rightarrow 2 \mathrm{HNO}_{3}(\mathrm{aq})$

Previous field measurements of $\mathrm{NO}_{3}$ include Geyer et al. $(2001 ; 2003)$ in which measurements of significant daytime mixing ratios of nitrate radical were as high as $30 \mathrm{ppt}$ beginning at 3 hours before sunset. Brown et al. (2005) conducted measurements of $\mathrm{NO}_{3}$ during the day with values of $0.5 \mathrm{pptv}$ recorded, which is highly reactive with $\alpha$-pinene, indicating that it can account for $10-40 \%$ of its oxidation. Sommariva et al. (2009) conducted measurements on the NOAA research vessel Ron Brown, and found that modeled $\mathrm{NO}_{3}$ was overestimated by $30-50 \%$ in the marine boundary layer at night and called for more studies of peroxy radicals and $\mathrm{NO}_{3}$ as a potential nighttime loss of $\mathrm{NO}_{3}$. Salisbury et al. (2001) conducted measurements of $\mathrm{HO}_{2}+\mathrm{RO}_{2}, \mathrm{NO}_{3}$ with DOAS, HCs and ozone at a coastal site in Ireland. They found the most important reactions at night with respect to radical production were $\mathrm{O}_{3}$ and $\mathrm{NO}_{3}$ reactions. $\mathrm{NO}_{3}$ reactions dominated in cleaner marine air from the West, and found that $\mathrm{NO}_{3}$ is both a source and sink of $\mathrm{RO}_{2}$.

Emerson and Carslaw (2009) performed a measurement campaign in rural area of the UK, 25 miles from London. Simultaneous measurements were made of meteorological conditions, aerosol size distribution and composition, concentrations of $\mathrm{HO}, \mathrm{HO}_{2}, \mathrm{HO}_{2}+\Sigma \mathrm{RO}_{2}$, non-methane hydrocarbons (NMHC), oxidized VOCs), $\mathrm{CO}, \mathrm{NO}, \mathrm{NO}_{2}, \mathrm{H}_{2} \mathrm{O}$, and $\mathrm{O}_{3}$. Although they did not measure $\mathrm{NO}_{3}$, they applied the Master Chemical Mechanism (MCM; Jenkin et al. 1997; 2003) to simulate it and found a nighttime average $\mathrm{NO}_{3}$ concentration of $0.6 \mathrm{ppt}$ for their conditions. Their model simulations estimated that $\mathrm{NO}_{3}$ initiated the formation of $33 \%$ of $\mathrm{RO}_{2}$ species.

Asaf et al. (2009) measured $\mathrm{NO}_{3}$ in an urban location for two years. The average nighttime concentration maximum was $200 \mathrm{ppt}$ with maximum levels exceeding $800 \mathrm{ppt}$. Their measurements showed $\mathrm{NO}_{3} \mathrm{was}$ inversely correlated with relative humidity and positively correlated with temperature and to a lesser extent with $\mathrm{NO}_{2}$ and $\mathrm{O}_{3}$, indicating that heterogeneous removal processes were also important.

Benton et al. (2010) measured the sum of $\mathrm{NO}_{3}+\mathrm{N}_{2} \mathrm{O}_{5}$ with a broadband cavity enhanced absorption spectroscopy system (BBCEAS) located 160m above street level in London. They found that $\mathrm{NO}_{3}$ 
concentrations were not likely to reach steady state during their campaign. Calculated lifetimes of $\mathrm{NO}_{3}$ were on the order of a few minutes. Crowley et al. (2010) measured $\mathrm{NO}, \mathrm{NO}_{2}, \mathrm{NO}_{3}$ and $\mathrm{N}_{2} \mathrm{O}_{5}$ at a rural mountain site in Germany. In remote areas, the lifetime of $\mathrm{NO}_{3}$ is controlled by reactions with VOCs. $\mathrm{NO}_{3}$ and $\mathrm{N}_{2} \mathrm{O}_{5}$ were measured using an off-axis cavity-ring-down system (OA-CRD).

Crowley et al. (2011) measured $\mathrm{NO}_{3}$ and $\mathrm{N}_{2} \mathrm{O}_{5}$ with OA-CRD on the Atlantic Coast of southern Spain in a forested area near both pollution sources and the Atlantic Ocean. $\mathrm{NO}_{3}$ lifetimes were longest in air masses originating over the Atlantic Ocean, and were very short (a few seconds) in polluted air masses.

Stone et al. (2014) measured $\mathrm{NO}_{3}, \mathrm{~N}_{2} \mathrm{O}_{5}, \mathrm{HO}$ and $\mathrm{HO}_{2}$ in an aircraft over the UK and the North Sea to assess the importance of nighttime chemistry on regional and global air quality. They attempted to interpret their observations using a zero-dimensional model using the Master Chemical Mechanism v3.2. They found that their model systematically underpredicted $\mathrm{HO}_{2}$ by approximately $200 \%$ and overpredicted $\mathrm{NO}_{3}$ and $\mathrm{N}_{2} \mathrm{O}_{5}$ by around 80 and $50 \%$, respectively.

These observations suggest that much more remains to be learned about production and loss processes for the nitrate radical. (Readers are directed to the excellent review article by Brown and Stutz (2012) for a more in depth look at nocturnal chemistry.) In this project our objective is to evaluate the impact of nitrate radical on the transformation and removal of atmospheric compounds under conditions of low relative humidity. This project provides the first continuous measurements of nitrate radical over a period of four weeks in an arid urban location, Reno, Nevada, USA.

\section{Site Description}

This study was performed at the Desert Research Institute (DRI) located at $39.52^{\circ} \mathrm{N} 119.81^{\circ} \mathrm{W}, 1509 \mathrm{~m}$ ASL) on a mesa to the north of Reno (about 400 meters from Highway US Route 395) during July and August of 2008. Reno is an urban area (population ca. 200,000) in a semi-arid valley between the Sierra Nevada and Virginia mountain ranges. Reno is bordered to the east by the city of Sparks. The RenoSparks metropolitan area is informally called the Truckee Meadows, and consists of about 400,000 residents. Due to the effect of the Sierra Nevada mountain range on wind flow patterns, pollutant concentrations in Reno, NV are mostly local in origin although some long-range transport from the San Francisco Bay Area and central California may occur.

The air quality in Reno is moderately polluted with peak ozone mixing ratios typically between 60 to about $95 \mathrm{ppb}$, peak $\mathrm{NO}_{\mathrm{x}}$ levels on the order of 50 to $80 \mathrm{ppb}$ and there are frequent episodes of high particulate concentrations (Stanley et al., 1997; Washoe County, 2014). These levels of $\mathrm{O}_{3}$ suggest that $\mathrm{NO}_{3}$ is not likely to reach detectable levels during the daytime because Geyer et al. 2003a required $\mathrm{O}_{3}$ mixing ratios exceeding $\sim 100 \mathrm{ppb}$ for nitrate radical to reach detectable levels. However, Reno is in a relatively deep valley with considerable shading (attenuating solar radiation) that reduces $\mathrm{NO}_{3}$ photolysis during the late afternoon.

The relative humidity in Reno, NV is low enough for hydrolysis to be slow, leading to concentrations of nitrate radical high enough to be observed. The average relative humidity is 26,18 and $35 \%$ at 10:00, 16:00 and 22:00, respectively, during July for the previous ten years (Western Regional Climate Center: www.wrcc.dri.edu). However, during this campaign (July 2008), relative humidities were even lower: 11, 
9 and 14\% at 10:00, 16:00 and 22:00, respectively. Givens the presence of high ozone, $\mathrm{NO}_{\mathrm{x}}$ and low relative humidity, the mixing ratios of nitrate radical were easily observed during the nighttime hours.

\subsection{Methods}

\subsection{Measurements}

Measurements were conducted nightly for VOCs and $\mathrm{NO}_{3}$ from 7 July 2008 to 8 August 2008. Long-path Differential Optical Absorbance Spectrometry (DOAS) is an established procedure for measuring gaseous constituents of the atmosphere, and is based on ultraviolet-visible absorption spectroscopy. A DOAS instrument has three necessary components: a source of broadband light, a focused light path long enough for significant absorbance by the constituent gases (e.g., a combination of telescope and reflectors) and a detector capable of measuring light intensity over a range of wavelengths (e.g., a multichannel spectrometer). What distinguishes DOAS from other forms of absorption spectroscopy is that it's a single-beam technique with the reference beam intensity estimated from an interpolated background. The DOAS instrument was used to measure the concentrations of the atmospheric species, $\mathrm{NO}_{3}, \mathrm{NO}_{2}, \mathrm{O}_{3}, \mathrm{CO}, \mathrm{SO}_{2}$ and $\mathrm{HCHO}$.

For this project, the DOAS was obtained on loan from the Air Quality Laboratory at the Institute of Earth Sciences, Hebrew University of Jerusalem. The system was manufactured by Hoffmann-Messtechnik, Rauenberg, Germany, and consists of a transmitting/receiving telescope housing, containing a light source and connected to a diffraction-grating spectrometer with a 1024 channel photodiode array detector. The DOAS system was mounted on the top floor of DRI's Northern Nevada Science Center (NNSC) building on the outskirts of the urban area. The light path was directed toward the south of DRI to a set of retroreflectors mounted on the rooftop of the Grand Sierra Resort in downtown Reno, a distance of 5.86 kilometers each way, Figure 1. (For detection limits of this and other instruments used in this study see Table 1.)

The field study provided four weeks of continuous measurements of nitrate radical, meteorological variables, particulate nitrate and sulfate, and ancillary species during the summer along with 30-minute integrated samples of hydrocarbons and aldehydes which were collected once or twice per day throughout the intensive, Tables 1 and 2. A wide range of relative humidities were expected due to the low absolute water vapor concentrations and the relatively strong diurnal temperature variations that occur in desert environments during the summer. Another major possibility that could affect the nitrate radical concentrations was wildfires that often occur and can significantly increase the concentrations of aerosol particles for weeks at a time. Some of the measurements were in fact made during wildfires that affected the Reno area.

Temperature, solar radiation, relative humidity, wind speed and direction, and barometric pressure were monitored continuously from sunset until sunrise along with mixing ratios of $\mathrm{NO}, \mathrm{NO}_{2}, \mathrm{O}_{3}$, total nitrogen oxides, $\mathrm{CO}, \mathrm{CO}_{2}$, and $\mathrm{SO}_{2}$ which were measured by real time analyzers using chemiluminescence or optical absorbance instrumentation from the Tennessee Valley Authority. Particulates were measured nightly by a Scanning Mobility Particle Sizer (SMPSTM) spectrometer for submicrometer particle sizing (obtained on loan from the Storm Peak Laboratory, Steam Boat Springs, CO for this project). 
Canister samples were collected for analysis volatile organic compounds on the rooftop of DRI, Table 1. These samples were then sent to the University of California, Irvine laboratory for analysis using three gas chromatography (GC) ovens coupled with a suite of detectors that together are sensitive to $76 \mathrm{C}_{2}-\mathrm{C}_{10}$ VOCs, using two flame ionization detectors (FIDs) to measure hydrocarbons, two electron capture detectors (ECDs) for halocarbons, and a quadrupole mass spectrometer detector (MSD) for sulfur compounds (Simpson et al. 2010). DNPH (2,4-dinitrophenylhydrazine) cartridge samples of aldehydes were collected using the EPA TO-11A method were made during the intensive, which were analyzed by the Organic Analytical Laboratory at DRI (see Table 1 for instrument description).

The time resolution for each instrument ranges from 5 to 15 minutes (all continuous meteorological measurements to 15 minutes DOAS measurements) and the recorded measurements were synchronized. VOC samples (canisters and DNPH cartridges) were also synchronized to cover the two fifteen-minute sampling intervals of the DOAS. It is evident that the DOAS is not a point measurement. However, the optical path was located so that the impact by local sources would be minimized. We believe the increased sensitivity of this measurement outweighed any uncertainties due to differences in spatial resolution. Furthermore, the differences in measurements of ozone and $\mathrm{NO}_{2}$ between the point samples and the DOAS were less than $10 \%$, therefore local effects were not observed.

The DOAS spectra were analyzed following well-established procedures for the identification and quantification of atmospheric gaseous species (e.g., Heintz et al. 1996; Geyer et al. 1999). Background spectra, dark current, and electronic offset were subtracted, followed by band-pass filtration of the resulting spectra. A fifth order polynomial and reference spectra for $\mathrm{NO}_{2}$ (measured on site), $\mathrm{NO}_{3}$ (literature values), and water vapor (from daytime spectra with no $\mathrm{NO}_{3}$ present) were fitted using nonlinear least-squares fitting routines by the analysis software MFC (Asaf et al. 2009).

The measurements of the $\mathrm{NO}_{3}$ concentrations and of the ancillary species were analyzed in order to evaluate their sources, chemical processes, oxidative capacity, sinks, and products. The important parameters governing the $\mathrm{NO}_{3}$ chemistry can be calculated from the ancillary data, including nitrate radical production rates, $\mathrm{NO}_{3}$ lifetime, concentrations of $\mathrm{N}_{2} \mathrm{O}_{5}$ (which is in equilibrium with nitrate radical and may serve as a major sink under some conditions), oxidation capacity, nitrate radical degradation frequency, and direct and indirect removal rates. The measured ancillary species were used to estimate the expected gas-phase losses of nitrate radical through reactions with $\mathrm{VOC}$ and $\mathrm{NO}_{\mathrm{x}}$.

Additional meteorological information was obtained using a miniSODAR (Atmospheric Systems Corporation, Santa Clarita, CA), which can measure the winds in the range of 30 to 200 meters above the ground in 5 meter increments; and a Vaisala Ceilometer CL-31, which measures vertical visibility with infrared light $(\lambda=910 \mathrm{~nm})$ to establish boundary layer heights as a function of time. The miniSODAR was located in the parking lot of DRI, while the ceilometer was located on the rooftop of DRI.

\subsection{Modeling}

The RACM2 mechanism (Goliff et al. 2013) was employed in a box model (SBOX: Seefeld 1997) to simulate ambient field data collected during the summer 2008 campaign. RACM2 uses a lumped molecular approach for representing atmospheric chemistry. It consists of 363 chemical reactions including 33 photolytic reactions and uses 120 chemical species to describe atmospheric chemistry. It uses kinetic data from several sources including the recent suggestions of IUPAC (IUPAC 2010) and 
NASA/JPL (Sander et al. 2011). It was evaluated by comparing simulation results with environmental chamber experimental data from the University of California, Riverside and the EXACT campaign (Goliff et al., 2013). For daytime simulations, photolysis frequencies were calculated from the absorption cross-sections and quantum yields referenced in (Goliff et al. 2013) and spectrally resolved actinic flux calculated according to Madronich (1987).

The box model SBOX using RACM2 was run with and without dry deposition for the following compounds: $\mathrm{O}_{3}, \mathrm{NO}_{2}, \mathrm{~N}_{2} \mathrm{O}_{5}, \mathrm{HNO}_{3}$ and PAN. Deposition rates were taken from Pugh et al. 2010 (ozone, $\mathrm{NO}_{2}$ and $\mathrm{HNO}_{3}$ ); Rohrer et al. $1998\left(\mathrm{~N}_{2} \mathrm{O}_{5}\right)$; and Schrimpf et al. 1996 (PAN). The model was constrained by observations of organic and inorganic compounds measured during the campaign. For the two case studies presented in this manuscript, initial conditions were taken from observations at the beginning of the night. Radical intermediates reach a steady state based on the initial concentrations within a few simulated seconds during a chemical box model simulation. No spin-up time is required because of the very rapid establishment of a steady state of the reactive intermediates and the box model assumption of instantaneous perfect mixing.

\section{Results and Discussion}

\subsection{Measurements}

Concentrations of $\mathrm{NO}_{3}$ were measured above the detection limit every night with the exception of shifted to the East). These nights were impacted by wildfires upwind in northern California. Severe light scattering from the fire-generated particles prevented the DOAS from making nitrate radical measurements during most of these three nights. During these nights there was elevated particulate matter, $\mathrm{CO}$, VOCs and $\mathrm{NO}_{2}$. The highest nighttime ozone observed throughout the field campaign was on the night of July 9-10, when ozone peaked at $88 \mathrm{ppb}$. Carbon monoxide, acetone and many measured aldehydes were elevated on these high $\mathrm{O}_{3}$ nights compared to the rest of the field campaign (Figure 2a-c).

The sampling location on the rooftop of DRI was in the free troposphere for much of the night throughout the campaign. This conclusion is supported by $\mathrm{CO}$ measurements conducted during the campaign. Figure 3 illustrates the CO and ozone concentrations for the night of July 13-14, 2008, in which spikes in the $\mathrm{CO}$ concentrations (the result of mobile emissions from the valley floor) are observed at 6 a.m. and 8 a.m. local time. We believe the first spike is due to updrafts of air due to warming of the hillside, and the second spike is due to the boundary layer height rising to the height of the sampling location. These pairs of $\mathrm{CO}$ spikes were observed every morning of the field campaign. In addition to the $\mathrm{CO}$ spikes, we observed concurrent dips in the ozone concentrations due to the titration of ozone by NO (also from mobile emissions).

Figure 4 shows the nocturnal half-hourly mixing ratios of $\mathrm{NO}_{3}$ measured by the DOAS during the entire measurement campaign. Higher concentrations were generally observed during the second half of the night, with levels dropping at dawn, which was approximately 5:30 a.m. local time. Table 3 shows the range and average nighttime concentrations for $\mathrm{NO}, \mathrm{NO}_{2}, \mathrm{NO}_{3}, \mathrm{O}_{3}$ and $\mathrm{CO}$ for the entire campaign. The highest concentrations of nighttime $\mathrm{NO}_{3}$ and $\mathrm{O}_{3}$ were observed on the nights when Reno air quality was influenced by wildfires in northern California. The highest $\mathrm{NO}_{2}$ values were observed during the hours of the early morning commute due to the presence of nearby US Route 395. 
The measured $\mathrm{NO}_{3}$ concentrations were not sensitive to relative humidity, the concentrations of $\mathrm{NO}_{2}$ or ozone during the entire campaign as shown by their lack of correlations in the data. However, $\mathrm{NO}_{3}$ did correlate with $\mathrm{NO}$, implying that $\mathrm{NO}$ concentrations were the main driver for $\mathrm{NO}_{3}$ destruction for the Reno conditions. Nighttime NO concentrations ranged from 0.004 to $3.86 \mathrm{ppb}$ throughout the campaign, with an average of $0.7 \mathrm{ppb}$. Possible local sources were soil and vehicle traffic from nearby highway US Route 395. As expected, NO concentrations inversely correlated with ozone concentrations.

Concentrations of total particle numbers were highest while Reno, Nevada was downwind of the wildfire event the nights of July 9-10, July 10-11, and July 12-13, 2008, peaking at 12000 particles per cubic centimeter. Particle concentrations on typical nights in Reno were in the vicinity of 2500 particles per cubic centimeter. Figure 5(a) shows the observed particle diameters for a night impacted by the fires, and Figure 5(b) shows particle diameters on a typical night. While the particles on a typical night show a bimodal distribution of diameters, this is not case for the night downwind of the California fires, during which the diameters are larger, peaking at around $200 \mathrm{~nm}$.

\subsubsection{Comparing model output to observations}

In this manuscript we present the results of box model simulations for two nights in Reno, NV: July 3031, 2008 (a typical night in Reno) and July 10-11 (a night impacted by wildfires from California). The difference between these nights is illustrated in Figure 6. On July 10-11 ozone and $\mathrm{NO}_{2}$ was higher for the first half of the night than July 30-31. NO was lower by about 50\% the night of July 10-11 for the entire night. $\mathrm{NO}_{3}$ measurements were sporadic for the first half of the night of July 10-11 due to high particle concentrations from the California wildfires interfering with the light path of the DOAS. For the second half of both nights, $\mathrm{NO}_{3}$ concentrations were slightly higher on July 30-31, 2008. The temperature and relative humidity for both nights were essentially the same.

Case Study \#1: the night of July 30-31, 2008 - a typical night in Reno, NV

During the night of July 30-31, 2008 in Reno, NV, ozone levels were approximately 50 ppb throughout the night, $\mathrm{NO}$ was $0.8 \mathrm{ppb}, \mathrm{NO}_{2}$ averaged $3 \mathrm{ppb}$, and $\mathrm{NO}_{3}$ was measured to be $5 \mathrm{ppt}$. The measured VOC/NOx ratio was 15 at 8:25 p.m. July 30 and 8 at 5:20 a.m. July 31 . The box model was able to reproduce the ozone, $\mathrm{NO}$, and $\mathrm{NO}_{3}$ levels (which were underestimated during the second half of the night), but not the $\mathrm{NO}_{2}$ concentrations. In fact, the model overestimated $\mathrm{NO}_{2}$ concentrations by factor of 3 during the night. Even when dry deposition is accounted for, model output for $\mathrm{NO}_{2}$ continues to be overestimated. There are several possible reasons for this. One is that the box model has greater mixing than what is realistic for nighttime conditions, even in the free troposphere. This explanation seems unlikely due to the fact that the DOAS measurements and point measurements are in good agreement. Another possible reason may be due to $\mathrm{N}_{2} \mathrm{O}_{5}$ uptake by aerosols. (Uptake efficiencies tend to be higher for $\mathrm{N}_{2} \mathrm{O}_{5}$ than $\mathrm{NO}_{3}$, so we will limit our discussion to $\mathrm{N}_{2} \mathrm{O}_{5}$ (Chang et al., 2011)). Therefore we added $\mathrm{N}_{2} \mathrm{O}_{5}$ uptake by aerosols to the model, using an uptake coefficient of 0.002 due to the low humidity. The model predicted $\mathrm{N}_{2} \mathrm{O}_{5}$ concentrations lowered by 1 ppt for the night of July $30-31$ and lowered by $0.5 \mathrm{ppt}$ on the night of July 10-11. Although there is a higher surface area density on the night of July 10-11, the aerosol is due to biomass burning, which contains a higher percentage of organic carbon (Singh et al. 2010), which has been shown to impede $\mathrm{N}_{2} \mathrm{O}_{5}$ uptake (Chang et al., 2011). Another possibility is that there is an additional, unaccounted for, removal mechanism for $\mathrm{NO}_{2}$. 
During the night of July 10-11, 2008, the measured VOC/NOx ratio was 108 at 11 p.m. on July 10 and 79 at 3a.m. July 11. The box model was able to replicate the ozone levels, underestimate NO concentrations by about $15 \%$, underestimate $\mathrm{NO}_{3}$ levels by an average of $50 \%$, and overestimate $\mathrm{NO}_{2}$ concentrations by $50 \%$ at the beginning of the night a factor of 2.5 during the second half of the night. Adding dry deposition to the model did little to change those numbers $(<5 \%)$. The model was less able to simulate observed values for these compounds possibly because the $\mathrm{VOC} / \mathrm{NO}_{\mathrm{x}}$ ratio was much higher than is typically observed in urban areas. $\mathrm{VOC} / \mathrm{NO}_{\mathrm{x}}$ ratios in the vicinity of 100 are typically found in remote areas where NO concentrations are very low. For this case study, NO is not low, rather VOC concentrations were very high due to the influence of the California wildfires.

\subsubsection{Process Analysis}

300

301

302

303

304

In many cases a steady state assumption for $\mathrm{NO}_{3}$ concentrations (defined as when the production and loss rates are equal and the concentration of the species is unchanged) is not valid due to the presence of $\mathrm{N}_{2} \mathrm{O}_{5}$ as a reservoir species which is in equilibrium with $\mathrm{NO}_{3}$ and $\mathrm{NO}_{2}$ (reaction 4) and the possibility of $\mathrm{N}_{2} \mathrm{O}_{5}$ removal by hydrolysis, aerosol uptake and deposition. For the conditions present in this study, the warmer temperatures and low $\mathrm{NO}_{2}$ concentrations allow for the system to reach steady state faster than most other scenarios (Brown et al., 2003), particularly when removal rates for $\mathrm{N}_{2} \mathrm{O}_{5}$ are slow (detailed below).

\section{$\underline{\text { July } 30-31,2008}$}

Reaction with $\mathrm{NO}_{3}$ was a significant loss process for the model species OLI (olefins with an internal double bond), DIEN (olefins with two double bonds), ISO (isoprene), and API ( $\alpha$-pinene). Table 4 illustrates the relative importance of $\mathrm{NO}_{3}$ reactions compared to $\mathrm{HO}$ and $\mathrm{O}_{3}$ reactions. $\mathrm{NO}_{3}$ reactions accounted for slightly more than half of the loss (60\%) of OLI, less than half of the loss (28\%) of DIEN, $60 \%$ of the loss for ISO, and $85 \%$ of API for most of the night. $\mathrm{NO}_{3}$ contributions for aldehyde degradation were much smaller, generally less than $10 \%$, and $20 \%$ for OLT (olefins with a terminal double bond).

\section{$\underline{\text { July } 10-11,2008}$}

Table 4-shows the relative loss rates for the model species OLI, DIEN, ISO and API for July 10-11, 2008. In the case of every model species, $\mathrm{NO}_{3}$ reactions are more important on July 10-11 than on July 30-31. This is likely because the model predicts lower HO concentrations of $7.6 \times 10^{-6} \mathrm{ppb}$ on July 10-11 (Figure 79 ) during the second half of the night compared to $3.6 \times 10^{-5} \mathrm{ppb}$ on July $30-31$. Figure 8 shows the predicted $\mathrm{HO}_{2}$ concentrations for each case study. While July 10-11 had lower $\mathrm{HO}$ concentrations than July 30-31, $\mathrm{HO}_{2}$ concentrations were higher: peak value of $4.7 \times 10^{-3} \mathrm{ppb} \mathrm{HO}_{2}$ on July 10-11 and $1.2 \times 10^{-}$ ${ }^{3} \mathrm{ppb} \mathrm{HO}_{2}$ on July 30-31. This may be because $\mathrm{CO}$ and formaldehyde (HCHO) were elevated on July 1011 (1318 ppbv CO and 27 ppbv HCHO on July 10-11 and 152 ppbv CO and 4.7 ppbv HCHO on July 3031 ), and served to convert $\mathrm{HO}$ to $\mathrm{HO}_{2}$ during the night.

\section{$\underline{\text { Case Study Comparisons }}$}


Figure 9 illustrates which reactions are most important for overall $\mathrm{HO}_{\mathrm{x}}\left(\mathrm{HO}+\mathrm{HO}_{2}\right)$ formation during the nighttime hours on July 10-11 and July 30-31, 2008. For both nights, the OLI $+\mathrm{O}_{3}$ and OLT $+\mathrm{O}_{3}$ reactions are most important, ranging from $68 \%-80 \%$ of the total $\mathrm{HOx}$ formation. The $\mathrm{ISO}+\mathrm{O}_{3}$ reaction is more important on the night of July 10-11 (with an average of 12\% contribution to HOx) than the night of July 30-31 (with an average of 4\% contribution), which was expected due to isoprene concentrations being 2 times greater on the night of July 10-11. The model species DCB1, DCB2 and EPX are products of the oxidation reactions of aromatic compounds and they react with ozone to form $\mathrm{HO}$ and/or $\mathrm{HO}_{2}$ in RACM2.

The calculated $\mathrm{HO}_{2} / \mathrm{HO}$ ratios were quite different for each case study: an average of 101 on July 30-31 and 185 on July 10-11 (Figure 10), even though the measured NO was lower on July 10-11; however, that night had elevated concentrations of $\mathrm{HCHO}$ and $\mathrm{CO}$ which also serve to convert $\mathrm{HO}$ to $\mathrm{HO}_{2}$. Elshorbany et al. (2012) state that a high $\mathrm{HO}_{2} / \mathrm{HO}$ ratio is typical for clean air with low NOx conditions. The model calculations in this study show a high $\mathrm{HO}_{2} / \mathrm{HO}$ ratio may also be seen with polluted air with low $\mathrm{NO}$ (NO $\approx 1 \mathrm{ppb}$ ) conditions as well.

While the most important removal mechanism during the nighttime hours for $\mathrm{NO}_{3}$ is reaction with $\mathrm{NO}$, the removal of $\mathrm{NO}_{3}$ by hydrocarbons varied with the two case studies discussed in this paper. Figure 11 shows OLT $+\mathrm{NO}_{3}$ (average of $6 \%$ ) OLI $+\mathrm{NO}_{3}$ (average of $41 \%$ ) and $\mathrm{ISO}+\mathrm{NO}_{3}$ (average of $42 \%$ ) as important for $\mathrm{NO}_{3}$ removal by hydrocarbons on both nights, although OLI is more dominant for much of the night on July 30-31 than on July 10-11 (average of 67\%).

Process analysis was also employed to investigate the importance of various reactions with regard to nitric acid $\left(\mathrm{HNO}_{3}\right)$ formation. For both case studies, the most important reaction was $\mathrm{NO}_{2}+\mathrm{HO}$. For the night of July 10-11, when VOC concentrations were elevated due to the wildfires in California, $\mathrm{NO}_{2}+$ $\mathrm{HO}$ accounted for $40 \%$ of nitric acid formation at the beginning of the night, and $80 \%$ at the end of the night (Figure 12), with the remainder due to oxygenated $\mathrm{VOCs}+\mathrm{NO}_{3}$ and other inorganic reactions. On July 30-31, $\mathrm{NO}_{2}+\mathrm{HO}$ accounted for $86 \%$ of the nitric acid formation for most of the night (Figure 12). Acetaldehyde (ACD in RACM2) was the most important contributor to nitric acid formation among the oxygenated VOCs reacting with $\mathrm{NO}_{3}(10 \%)$.

Because the model overpredicts $\mathrm{NO}_{2}$, we adjusted the model parameters to force a fit to observed $\mathrm{NO}_{2}$ concentrations. Under these conditions, the $\mathrm{NO}_{2}+\mathrm{HO}$ reaction accounted for $76 \%$ of nitric acid formation for most of the night of July 30-31, while the impact of this reaction remained unchanged for the night of July 10-11, and remains the most important $\mathrm{HNO}_{3}$ formation reaction in these case studies. An additional consequence of the model adjustment, the hydroxyl radical concentrations dropped $4 \%$ for the night of July 30-31 and $0.4 \%$ for the night of July 10-11.

\section{Conclusions}

Nighttime concentrations of nitrate radical were successfully measured during a four week field campaign in an arid urban location, Reno Nevada. While typical concentrations of $\mathrm{NO}_{3}$ ranged from 5 to $20 \mathrm{ppt}$, elevated concentrations were observed during a wildfire event. On a typical night in Reno, Nevada, $\mathrm{NO}_{3}$ accounted for approximately half of the loss of olefins, $60 \%$ of the isoprene loss, and $85 \%$ of the $\alpha$-pinene loss during the nighttime hours. The $\mathrm{NO}_{3}+$ aldehyde reactions were not as important as anticipated. On a polluted night with elevated VOCs. For both case studies discussed here, inorganic chemistry was the 
biggest influence on $\mathrm{NO}_{3}$ concentrations and on nitric acid formation. Model simulations overpredicted $\mathrm{NO}_{2}$ concentrations for both case studies. This may be due to $\mathrm{NO}_{2}$ removal processes that were not accounted for. It's also possible that the box model may have greater than realistic mixing then suitable for simulating the measurement period. However, the sampling location was in the free troposphere, above the boundary layer every night, so it's unlikely that the air was stagnant. Future studies include box modeling with dilution terms simulating horizontal dispersion, examination of the impact of different chemical mechanisms on model simulations and analysis of the effects of mountain meteorology with a 1D model to further explore the impact of mixing on $\mathrm{NO}_{2}$ and $\mathrm{CO}$ concentrations, as well as vertical flux and deposition.

\section{Acknowledgements}

The authors gratefully acknowledge the Facilities Department at the Desert Research Institute for remodeling the Science Tower specifically for the purposes of conducting the field campaign discussed in this manuscript. We also thank Dr. Ming Xiao for assistance with the SMPS data, Dr. David DuBois for assistance with the ceilometer data, and Ms. Michelle Breckner for her assistance with the miniSODAR at Desert Research Institute. NSF provided funding through NSF Award Number: 0701221 for this project and the NSF Research Experiences for Undergraduates program to the Desert Research Institute. NSF provided funding through NSF Award Number: 0653997 for this project. The authors thank the National Oceanic and Atmospheric Administration for a grant to Howard University's NOAA Center for Atmospheric Sciences and the National Aeronautics and Space Administration for a grant to "Howard University Beltsville Center for Climate System Observation," these grants helped support the data analysis. The authors thank Howard University graduate student Tatiana D. Gonzalez for helpful discussions. The authors also thank University of Nevada Reno undergraduate student Ramona Hull for assistance in running the SBOX model for the case studies. The opinions expressed in this publication are those of the authors alone and do not reflect the policy of any government agency.

\section{References}

Asaf D., Pedersen D., Matveev V., Peleg M., Kern C., Zingler J., Platt U., and Luria M., 2009: LongTerm Measurements of $\mathrm{NO}_{3}$ Radical at a Semiarid Urban Site: 1 . Extreme Concentration Events and Their Oxidation Capacity, Environ. Sci. Technol. 43 (24), 9117-9123.

\section{Atkinson et al. 2006: http://www.iupac-kinetic.ch.cam.ac.uk/}

Brown, S. S., H. Stark, and A. R. Ravishankara, Applicability of the steady state approximation to the interpretation of atmospheric observations of $\mathrm{NO}_{3}$ and $\mathrm{N}_{2} \mathrm{O}_{5}$, J. Geophys. Res., 108(D17), 4539, doi:10.1029/2003JD003407, 2003.

Brown, S.S., Dubé, W.P., Peischl, J., Ryerson, T.B., Atlas, E., Warneke, C., de Gouw, J.A., te Lintel Hekkert, S., Brock, C.A., Flocke, F., Trainer, M., Parrish, D.D., Feshenfeld, F.C., Ravishankara, A.R., 2011: Budgets for nocturnal VOC oxidation by nitrate radicals aloft during the 2006 Texas Air Quality Study, J. Geophys. Res. 116, D24305. doi:10.1029/2011JD016544

Brown, S. S., \& Stutz, J. (2012). Nighttime radical observations and chemistry. Chemical Society Reviews, 41(19), 6405-6447. 
Calvert J. G. and Stockwell W. R., 1983: Acid generation in the troposphere by gas-phase chemistry, Environ. Sci. Technol. 17 (9), pp 428A-443A DOI: 10.1021/es00115a727

Cantrell, Christopher A., Stockwell, William R., Anderson, Larry G., Busarow, Kerry L., Perner, Dieter, Schmeltekopf, Art, Calvert, Jack G., and Johnston, Harold S., 1985: Kinetic study of the nitrate free radical $\left(\mathrm{NO}_{3}\right)$-formaldehyde reaction and its possible role in nighttime tropospheric chemistry, J. Phys. Chem. 89 (1), 139-146.

Chang, W. L., Bhave, P. V., Brown, S. S., Riemer, N., Stutz, J., Dabdub, D., 2011: Heterogeneous atmospheric chemistry, ambient measurements, and model calculations of $\mathrm{N}_{2} \mathrm{O}_{5}$. A review, Aerosol Sci. Technol. 45, 665-695, doi:10.1080/02786826.2010.551672.

Dimitroulopoulou, C., Marsh, A.R.W., 1997: Modelling studies of $\mathrm{NO}_{3}$ nighttime chemistry and its effects on subsequent ozone formation, Atmos. Environ. 31(18), Pages 3041-3057. (http://www.sciencedirect.com/science/article/pii/S1352231097000332)

Elshorbany, Y. F., et al., 2012: HOx budgets during HOxComp: A case study of HOx chemistry under NOx-limited conditions, J. Geophys. Res. 117, D03307, doi:10.1029/2011JD017008.

Frost, G. J., et al., 2006: Effects of changing power plant NOx emissions on ozone in the eastern United States: Proof of concept, J. Geophys. Res. 111, D12306, doi:10.1029/2005JD006354.

Geyer, A., B. Alicke, S. Konrad, J. Stutz, and U. Platt, 2001: Chemistry and oxidation capacity of the nitrate radical in the continental boundary layer near Berlin, J. Geophys. Res., 106, 8013-8025.

Geyer, A., Bachmann, K., Hofzumahaus, A., Holland, F., Konrad, S., Klupfel, T., Patz, H.-W., Perner, D., Mihelcic, D., Schafer, H.-J., Volz-Thomas, A., Platt, U., 2003: Nighttime formation of peroxy and hydroxyl radicals during the BERLIOZ campaign: Observations and modeling studies, J. Geophys. Res. 108, 8249, doi:10.1029/2001JD000656.

Goliff, Wendy S., Stockwell William R., Lawson Charlene V., 2013: The regional atmospheric chemistry mechanism, version 2, Atmos. Environ. 68, 174-185, ISSN 1352-2310, 10.1016/j.atmosenv.2012.11.038.

IUPAC 2010: http://www.iupac-kinetic.ch.cam.ac.uk/

Jenkin, M.E., S.M. Saunders, and M.J. Pilling, 1997: The tropospheric degradation of volatile organic compounds: A protocol for mechanism development, Atmos. Environ. 31, 81-104.

Jenkin, M.E., S.M. Saunders, V. Wagner, and M.J. Pilling, 2003: Protocol for the development of the Master Chemical Mechanism, MCM v3 (Part B): tropospheric degradation of aromatic volatile organic compounds, Atmos. Chem. Phys. 3, 181-193.

Johnston, H. S., Cantrell, C. A., Calvert, J. G., 1986: Unimolecular Decomposition of $\mathrm{NO}_{3}$ to Form NO and $\mathrm{O}_{2}$ and $\mathrm{A}$ Review of $\mathrm{N}_{2} \mathrm{O}_{5} / \mathrm{NO}_{3}$ Kinetics, J. Geophys. Res. 91(D4), 5159-5172, doi:10.1029/JD091iD04p05159. 
Madronich, S.. 1987: Photodissociation in the Atmosphere; 1. Actinic Flux and the Effects on Ground Reflections and Clouds.. J. Geophys. Res. 92, 9740-9752

$\mathrm{Ng}$, N. L., et al., 2007: Effect of NOx level on secondary organic aerosol (SOA) formation from the photooxidation of terpenes, Atmos. Chem. Phys. 7, 5159-5174.

Pugh, T. A. M., Ryder J., MacKenzie, A. R., Moller, S. J., Lee, J. D., Helfter C., Nemitz E., Lowe D., Hewitt C. N., 2010: Modelling chemistry in the nocturnal boundary layer above tropical rainforest and a generalized effective nocturnal ozone deposition velocity for sub-ppbv NOx conditions, J Atmos. Chem. 65, 89-110, DOI 10.1007/s10874-011-9183-4

Rohrer F., Brüning D., Grobler E. S., Weber M. Ehhalt D. H. Neubert, R. Schüßler W. Levin I., 1998: Mixing Ratios and Photostationary State of $\mathrm{NO}$ and $\mathrm{NO}_{2}$ Observed During the POPCORN Field Campaign at a Rural Site in Germany, J Atmos. Chem 31, 119-137.

Sander, S.P., Abbatt, J.P.D., Barker, J.R., Burkholder, J.B., Friedl, R.R., Golden, D.M., Huie, R.E., Kolb, C.E., Kurylo, M.J.., Moortgat, G.K., Orkin, V.L., Wine, P.H., 2011: Chemical Kinetics and Photochemical Data for Use in Atmospheric Studies, Evaluation No. 17; Jet Propulsion Laboratory: Pasadena, CA.

Schrimpf, W., Lienaers, K., Muller, K.P., Rudolph, J., Neubert, R., Schüßler, W., Levin, I., 1996: Dry Deposition of peroxyacetyl nitrate (PAN): Determination of its deposition velocity at night from measurements of the atmospheric PAN and ${ }^{222}$ Radon concentration gradient, Geophys. Res. Lett. 23, 3599-3602.

Seefeld, S., 1997. Laboratory kinetic and atmospheric modelling studies of the role of peroxyacyl nitrates in tropospheric photooxidant formation. Ph.D. Thesis, Swiss Federal Institute of Technology, Zürich, Switzerland.

Simpson, I. J., Blake N. J., Barletta B., Diskin G. S., Fuelberg H. E., Gorham K., Huey L. G., Meinardi S., Rowland F. S., Vay S. A., Weinheimer A. J., Yang M., and Blake D. R., 2010: Characterization of trace gases measured over Alberta oil sands mining operations: 76 speciated $\mathrm{C}_{2}-\mathrm{C}_{10}$ volatile organic compounds (VOCs), $\mathrm{CO}_{2}, \mathrm{CH}_{4}, \mathrm{CO}, \mathrm{NO}, \mathrm{NO}_{2}, \mathrm{NO}_{\mathrm{y}}, \mathrm{O}_{3}$ and $\mathrm{SO}_{2}$, Atmos. Chem. Phys. 10, 11931-11954.

Singh, H. B., et al. "Pollution influences on atmospheric composition and chemistry at high northern latitudes: Boreal and California forest fire emissions." Atmospheric Environment 44.36 (2010): 45534564.

Stanley, Wei Yang Brian L. Jennison, and T. Omaye. "Air pollution and asthma emergency room visits in Reno, Nevada." Inhalation toxicology 9.1 (1997): 15-30.

Stelson A.W., Seinfeld J.H., 1982: Relative humidity and temperature dependence of the ammonium nitrate dissociation constant, Atmos. Environ. 196716 (5), 983-992. (http://www.sciencedirect.com/science/article/pii/0004698182901846)

Stone, D., Evans, M. J., Walker, H., Ingham, T., Vaughan, S., Ouyang, B., ... \& Heard, D. E. (2014). Radical chemistry at night: comparisons between observed and modelled $\mathrm{HOx}, \mathrm{NO}_{3}$ and $\mathrm{N}_{2} \mathrm{O}_{5}$ during the RONOCO project. Atmospheric Chemistry and Physics, 14(3), 1299-1321. 
485 Wahner, Andreas, Thomas F. Mentel, and Martin Sohn. "Gas $\square$ phase reaction of N2O5 with water vapor: 486 Importance of heterogeneous hydrolysis of N2O5 and surface desorption of HNO3 in a large Teflon 487 chamber." Geophysical Research Letters 25.12 (1998): 2169-2172.

488 Washoe County (2014). Washoe County, Nevada air quality trends (2004-2013). prepared by Washoe 489 County Health District, Air Quality Management Division, Reno, NV,

490 http://www.washoecounty.us/repository/files/4/AQ-Trends-2004-13.pdf.

491 
493 Table 1. Instrumentation of ancillary species for field studies.

\begin{tabular}{|c|c|c|c|c|}
\hline Pollutant & Symbol & $\begin{array}{l}\text { Manufacturer \& } \\
\text { model }\end{array}$ & $\begin{array}{l}\text { Detection } \\
\text { Limit }\end{array}$ & Principle of Operation \\
\hline Ozone & $\mathrm{O}_{3}$ & $\begin{array}{l}\text { Dasibi 1008-AH } \\
\text { and DOAS }\end{array}$ & $2 \mathrm{ppb}$ & U.V. photometric and light absorption \\
\hline Nitric oxide & $\mathrm{NO}$ & TEII $42 \mathrm{~S}$ & $0.2 \mathrm{ppb}$ & Chemiluminescence \\
\hline $\begin{array}{l}\text { Total nitrogen } \\
\text { oxides }\end{array}$ & $\mathrm{NO}_{\mathrm{y}}$ & $\begin{array}{l}\text { TEII } 42+\text { ext. Mo } \\
\text { converter }\end{array}$ & $0.2 \mathrm{ppb}$ & Chemiluminescence \\
\hline $\begin{array}{l}\text { Nitrogen } \\
\text { Dioxide }\end{array}$ & $\mathrm{NO}_{2}$ & $\begin{array}{l}\text { DOAS* and TEII } \\
42 \mathrm{~S}\end{array}$ & $0.1 \mathrm{ppb}$ & Light absorption \\
\hline Nitrate radical & $\mathrm{NO}_{3}$ & DOAS* & $5 \mathrm{ppt}$ & Light absorption \\
\hline Total nitrate & $\mathrm{NO}_{3^{-}}$ & $\begin{array}{l}\text { TEII } 42+\text { ext. Mo } \\
\text { converter }\end{array}$ & $0.2 \mathrm{ppb}$ & $\begin{array}{l}\text { Chemiluminescence, the measurement } \\
\text { used another } \mathrm{NOy} \text { monitor with a } \\
\text { nylon filter upstream, and } \mathrm{NO}_{3} \text { - was } \\
\text { calculated from the difference between } \\
\text { the two instruments. }\end{array}$ \\
\hline Total sulfate & $\mathrm{SO}_{4--}$ & $\begin{array}{l}\text { TEI Model } 5020 \\
\text { SPA (Sulfate } \\
\text { Particulate } \\
\text { Analyzer) }\end{array}$ & $\begin{array}{l}0.50 \mu \mathrm{g} / \mathrm{m}^{3} \\
(15 \text { minute } \\
\text { cycle })\end{array}$ & $\begin{array}{l}\text { Converts } \mathrm{SO}_{4} \text { to } \mathrm{SO}_{2} \text { using a thermal } \\
\text { reduction technique. } \mathrm{SO}_{2} \text { is then analyzed } \\
\text { using pulsed fluorescence spectroscopy. } \\
\text { The result is a continuous analyzer } \\
\text { producing data points every } 10 \text { seconds }\end{array}$ \\
\hline Formaldehyde & $\mathrm{HCHO}$ & $\begin{array}{l}\text { DNPH and } \\
\text { DOAS* }\end{array}$ & $50 \mathrm{ppt}$ & $\begin{array}{l}\text { Extraction from DNPH followed by } \\
\text { IC, and light absorption }\end{array}$ \\
\hline $\begin{array}{l}\text { Carbon } \\
\text { monoxide }\end{array}$ & $\mathrm{CO}$ & $\begin{array}{l}\text { Aero-Laser Model } \\
\text { AL5002 }\end{array}$ & $2 \mathrm{ppb}$ & $\begin{array}{l}\text { vacuum UV fluorescence, instrument } \\
\text { with } 1 \mathrm{~s} \text { response time }\end{array}$ \\
\hline Sulfur dioxide & $\mathrm{SO}_{2}$ & TEII 43S & $0.1 \mathrm{ppb}$ & pulsed fluorescence \\
\hline $\begin{array}{l}\text { Volatile } \\
\text { Organic } \\
\text { Compounds }\end{array}$ & VOC & $\begin{array}{l}\text { Varian Saturn } \\
2000 \text { mass } \\
\text { spectrometer, } \\
\text { Varian } 3800 \mathrm{GC}, \\
\text { and Entech } 7100\end{array}$ & $\begin{array}{c}0.01-0.05 \\
\text { ppbv }\end{array}$ & Canisters analyzed by GC/FID/MS \\
\hline Aldehydes & $\mathrm{RCHO}$ & $\begin{array}{l}\text { Waters } 2695 \\
\text { Alliance } \\
\text { Separation Module }\end{array}$ & $0.1 \mathrm{ppbv}$ & $\begin{array}{l}\text { DNPH (2,4-dinitrophenylhydrazine) } \\
\text { cartridges }\end{array}$ \\
\hline $\begin{array}{l}\text { Particle size } \\
\text { distribution } \\
\text { and number } \\
\text { density }\end{array}$ & $\begin{array}{l}0.1-10 \\
\mu \mathrm{m}\end{array}$ & $\begin{array}{l}\text { SMPS: } 3080 \mathrm{~N} \\
\text { Electrostatic } \\
\text { Classifier and } \\
\text { CPC } 3025 \\
\text { Condensation } \\
\text { Particle } \\
\text { Counter (TSI) }\end{array}$ & $\begin{array}{c}2 \times 10^{2} \text { to } 5 \times \\
10^{7} \text { part./. } \mathrm{cm}^{3} \text { in } \\
\text { number } \\
\text { concentration } \\
\text { for } \\
\text { monodisperse } \\
50 \text { nm particles) }\end{array}$ & $\begin{array}{l}\text { electrical-mobility } \\
\text { particle size classification, combined } \\
\text { with a Condensation } \\
\text { Particle Counter (CPC) }\end{array}$ \\
\hline
\end{tabular}


Table 2. Meteorological instrumentation for field studies.

\begin{tabular}{lllcl}
\hline $\begin{array}{l}\text { Meteorological } \\
\text { variable }\end{array}$ & Symbol & $\begin{array}{l}\text { Manufacturer } \\
\text { \& model }\end{array}$ & Sensitivity & Principle of Operation \\
\hline Wind direction & WDD & MET-ONE 24A & $5^{\circ}$ & Wind vane \\
Wind speed & WDS & MET-ONE 21A & $0.5 \mathrm{~m} / \mathrm{s}$ & 3-cup anemometer \\
Temperature & T & MET-ONE 60A & $0.5^{\circ} \mathrm{C}$ & Thermistor \\
Relative humidity & RH & MET-ONE 83A & $3 \%$ & Capacitance \\
Barometric pressure & Press & MKS-Baratron & 0.2 torr & Transducer \\
\hline
\end{tabular}

Table 3. Range and average values of nighttime $\mathrm{NO}, \mathrm{NO}_{2}, \mathrm{NO}_{3}$ and $\mathrm{O}_{3}$ throughout the campaign.

\begin{tabular}{lll}
\hline Compound & Range & Average \\
\hline $\mathrm{NO}$ & $0.004-3.9 \mathrm{ppb}$ & $0.71 \mathrm{ppb}$ \\
$\mathrm{NO}_{2}$ & $0.45-35 \mathrm{ppb}$ & $3.6 \mathrm{ppb}$ \\
$\mathrm{NO}_{3}$ & $0-150 \mathrm{ppt}$ & $11 \mathrm{ppt}$ \\
$\mathrm{O}_{3}$ & $17-85 \mathrm{ppb}$ & $51 \mathrm{ppb}$
\end{tabular}

Table 4. The relative importance of $\mathrm{NO}_{3}$ reactions compared to $\mathrm{HO}$ and $\mathrm{O}_{3}$.

\begin{tabular}{lllll}
\hline Date & Model Species & $\mathbf{N O}_{\mathbf{3}}$ & HO & $\mathbf{O}_{\mathbf{3}}$ \\
\hline July 10-11 & OLI & $36 \%$ & $3.5 \%$ & $60 \%$ \\
(wildfire event) & DIEN & $16 \%$ & $59 \%$ & $25 \%$ \\
& ISO & $44 \%$ & $36 \%$ & $21 \%$ \\
& API & $71 \%$ & $3 \%$ & $25 \%$ \\
July 30-31 & & & & \\
(Typical night) & OLI & $49 \%$ & $10 \%$ & $42 \%$ \\
& DIEN & $11 \%$ & $80 \%$ & $9 \%$ \\
& ISO & $34 \%$ & $57 \%$ & $8 \%$ \\
& API & $79 \%$ & $7 \%$ & $14 \%$
\end{tabular}


Figure 1 Schematic of DOAS setup. The DOAS is located at DRI, with reflectors located on the hotel roof.

Figure 2 Time series for measured (a) CO, (b) acetone, and (c) aldehydes, with periods of elevated concentrations associated with the wildfire event

Figure 3 Ozone and CO concentrations during the night and early morning of July 13-14, 2008

Figure 4 Summary of $\mathrm{NO}_{3}$ measurements throughout campaign. The average mixing ratio is depicted by blue diamonds, with the error bars showing the standard deviation of the mean.

Figure 5 Comparison of particle size distribution for a night impacted by (a) wildfires and (b) a typical night

Figure 6 Comparison of the nights of July 10-11, 2008 and July 30-31, 2008 for (a) ozone, (b) $\mathrm{NO}_{2}$, (c) $\mathrm{NO}$, and (d) $\mathrm{NO}_{3}$ including measurements and 0-D model output

Figure 7 Model predictions for HO concentrations for the nights of July 10-11 and July 30-31, 2008

Figure 8 Model predictions for $\mathrm{HO}_{2}$ concentrations for the nights of July 10-11 and July 30-31, 2008

Figure 9 Total $\mathrm{HOx}\left(\mathrm{HO}+\mathrm{HO}_{2}\right)$ formation rates during the nights of July 10-11 (polluted night) and 519 July 30-31 (typical night) in Reno, NV

520 Figure 10 Modeled $\mathrm{HO}_{2} / \mathrm{HO}$ Ratios for July 10-11 and July 30-31

Figure 11 Relative removal rates of $\mathrm{NO}_{3}$ by hydrocarbons for (a) July 10-11, and (b) July 30-31, 2008

Figure 12 Relative rates of nitric acid formation on (a) July 10-11, 2008 and (b) July 30-31, 2008 in Reno, NV 


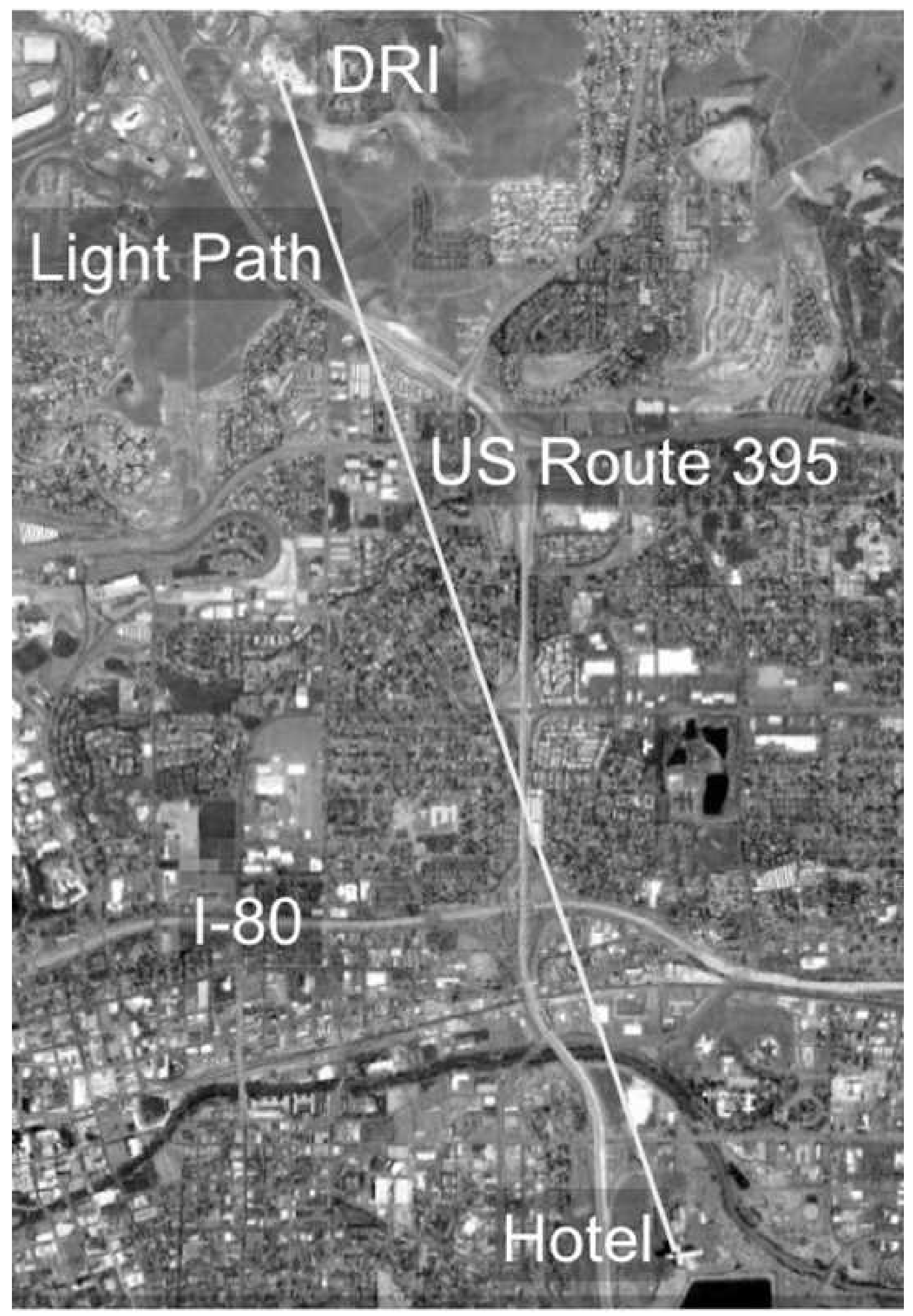




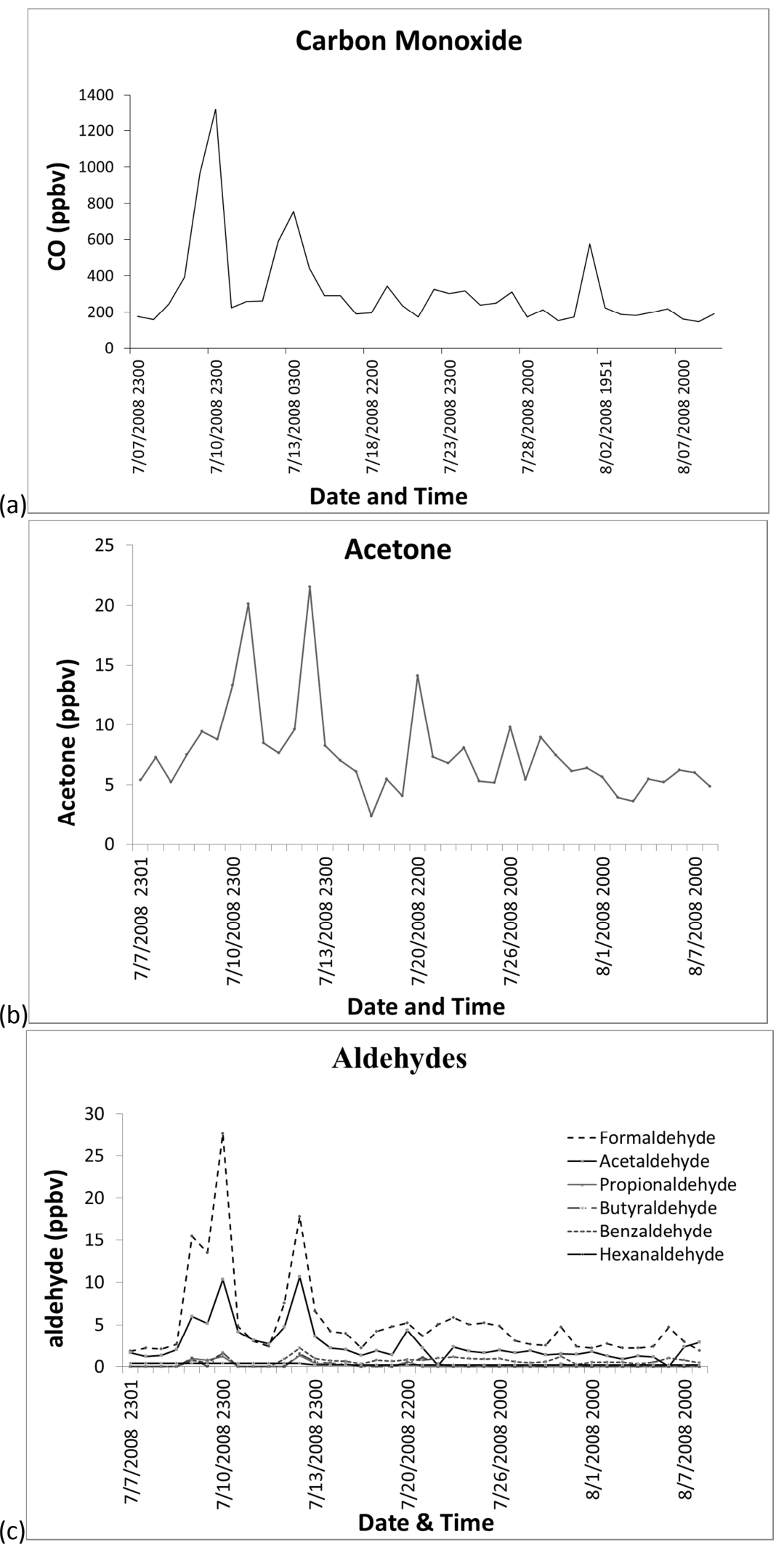




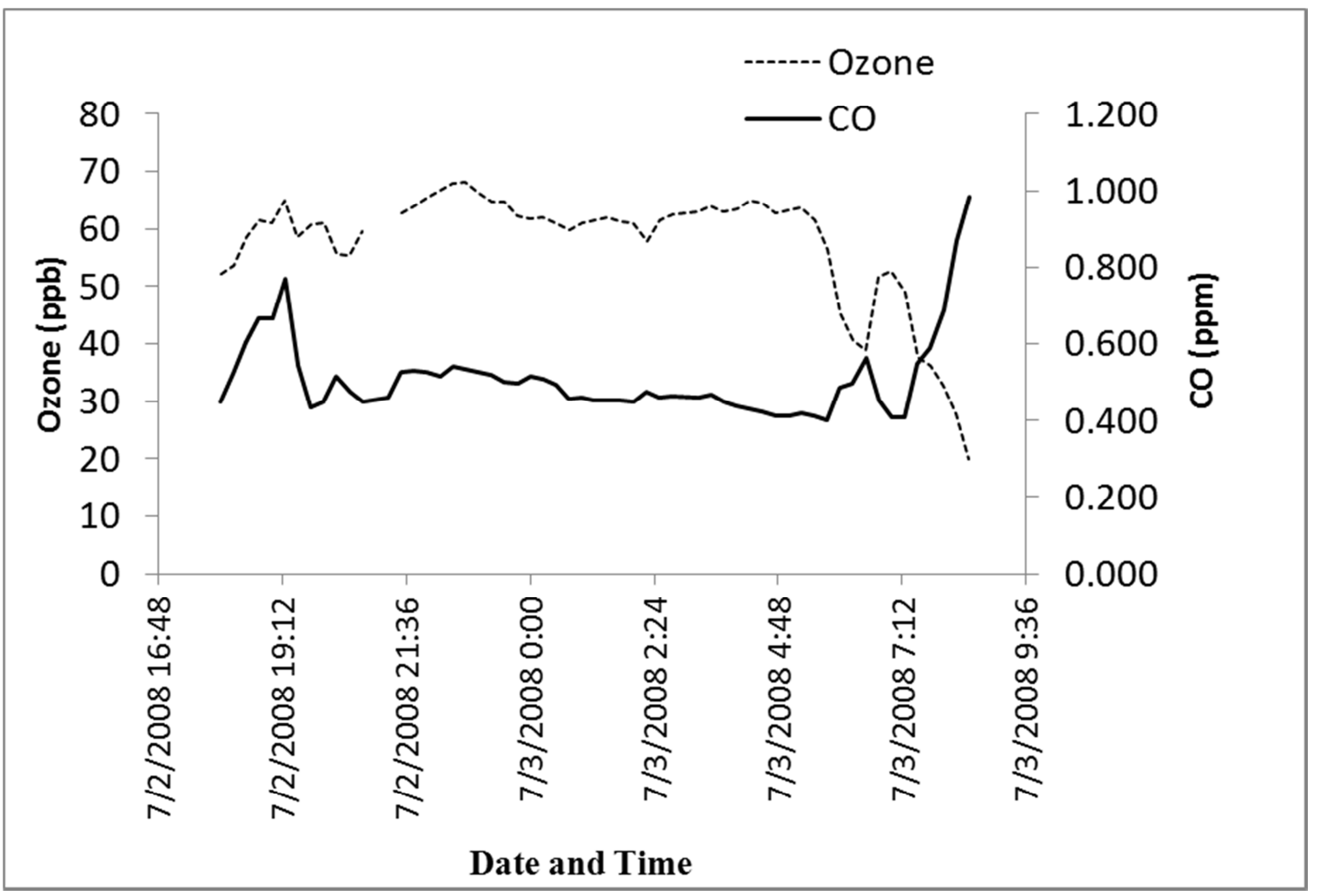




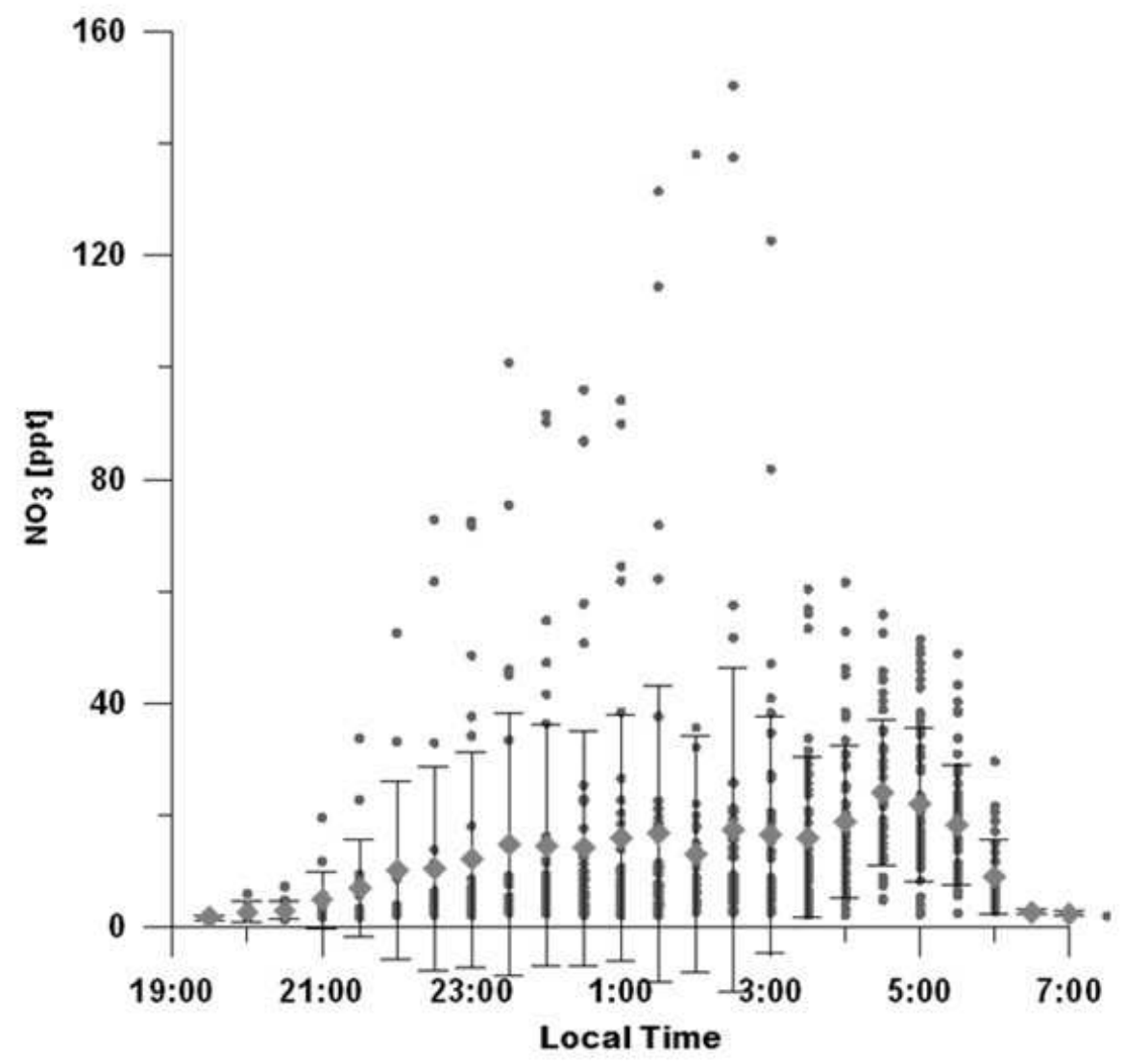


SMPS 07_09_2008

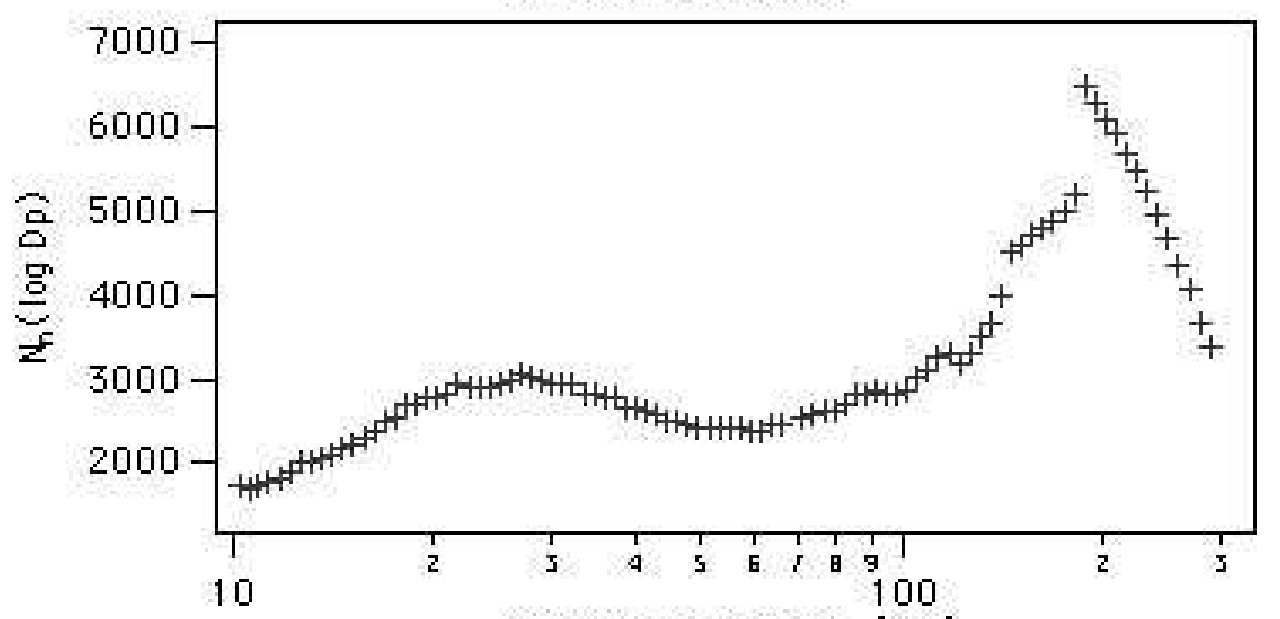

a

Mobility Diameter $d_{m}[\mathrm{~nm}]$

SMPS 07_15_2008

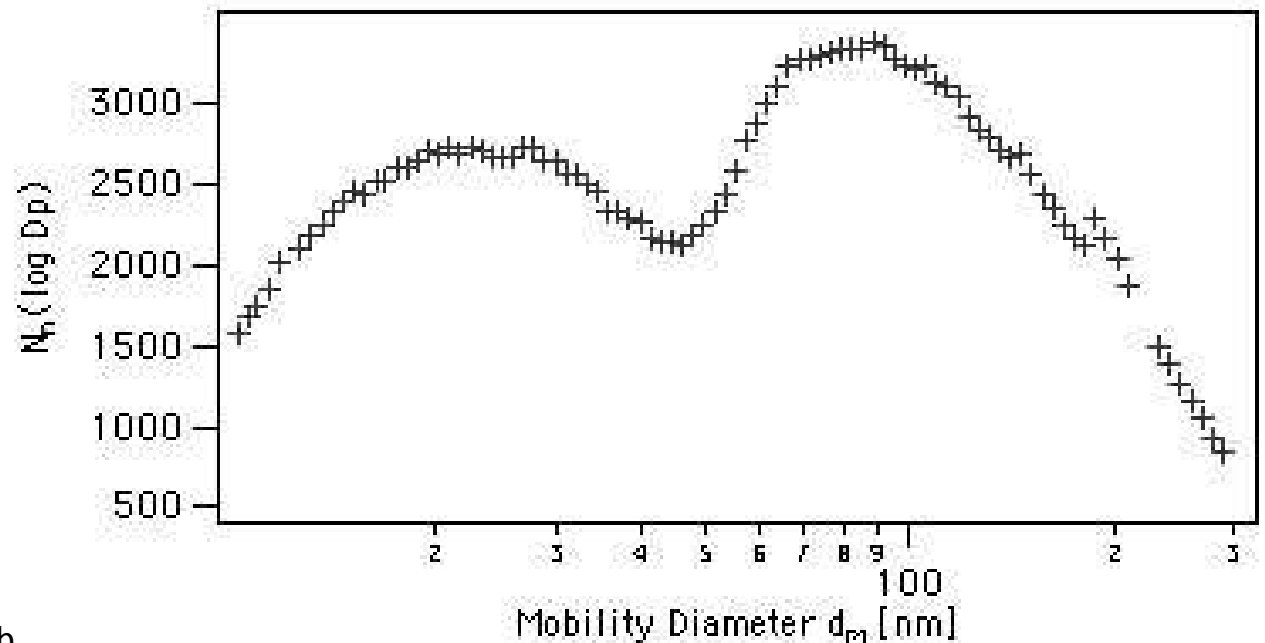

b

Mobility Diameter $\mathrm{d}_{\mathrm{m}}[\mathrm{nm}]$ 


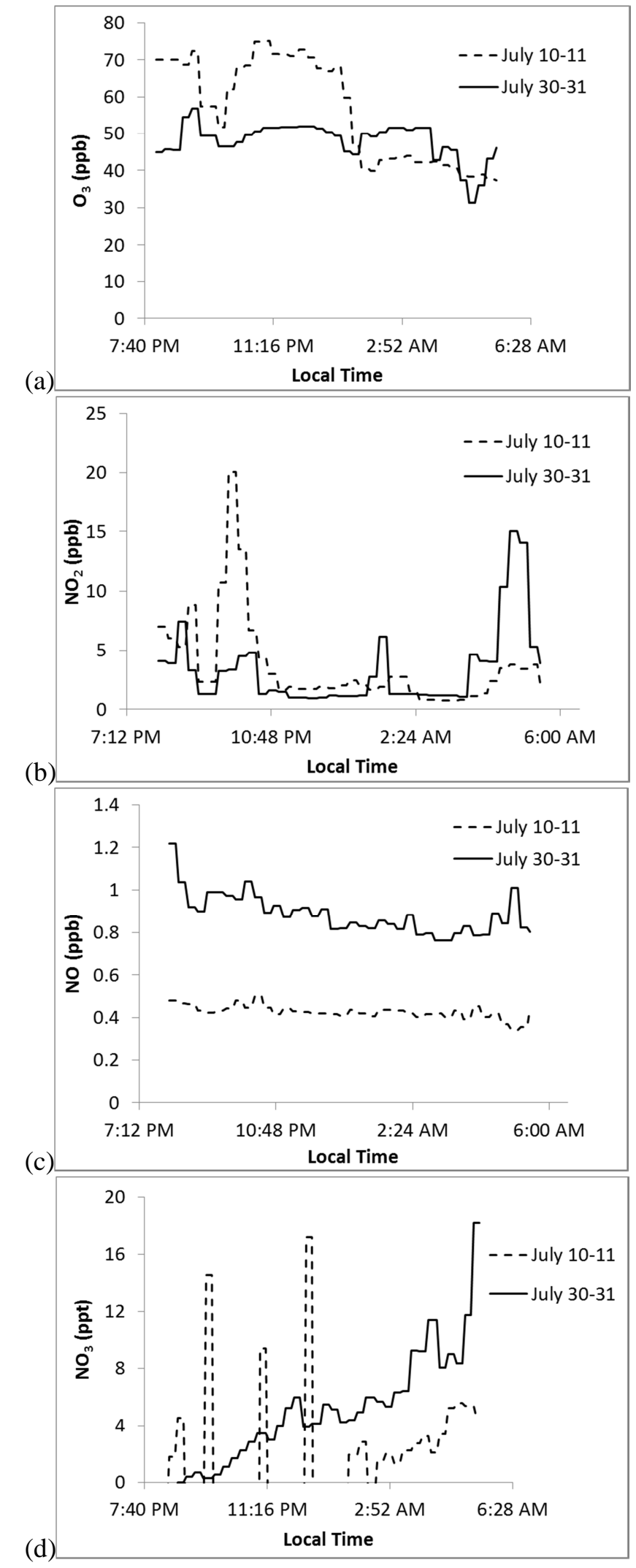




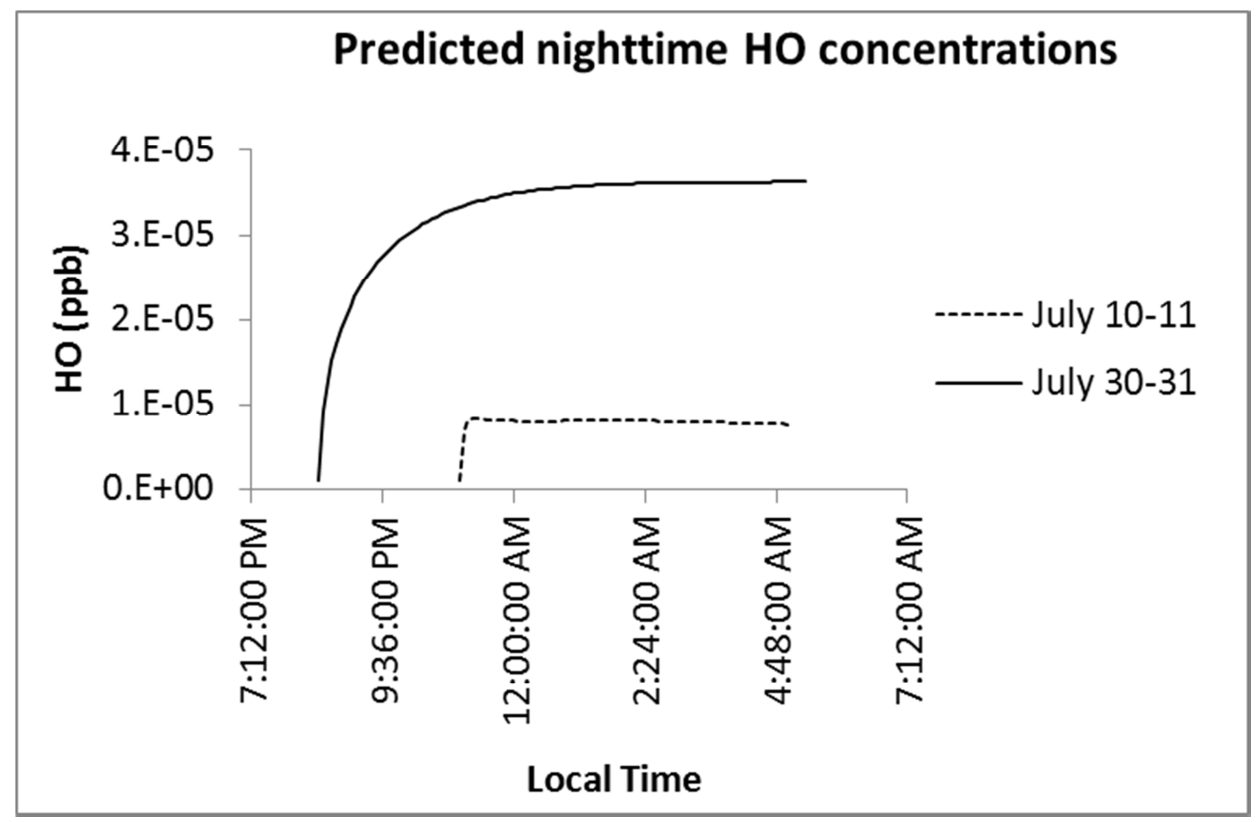




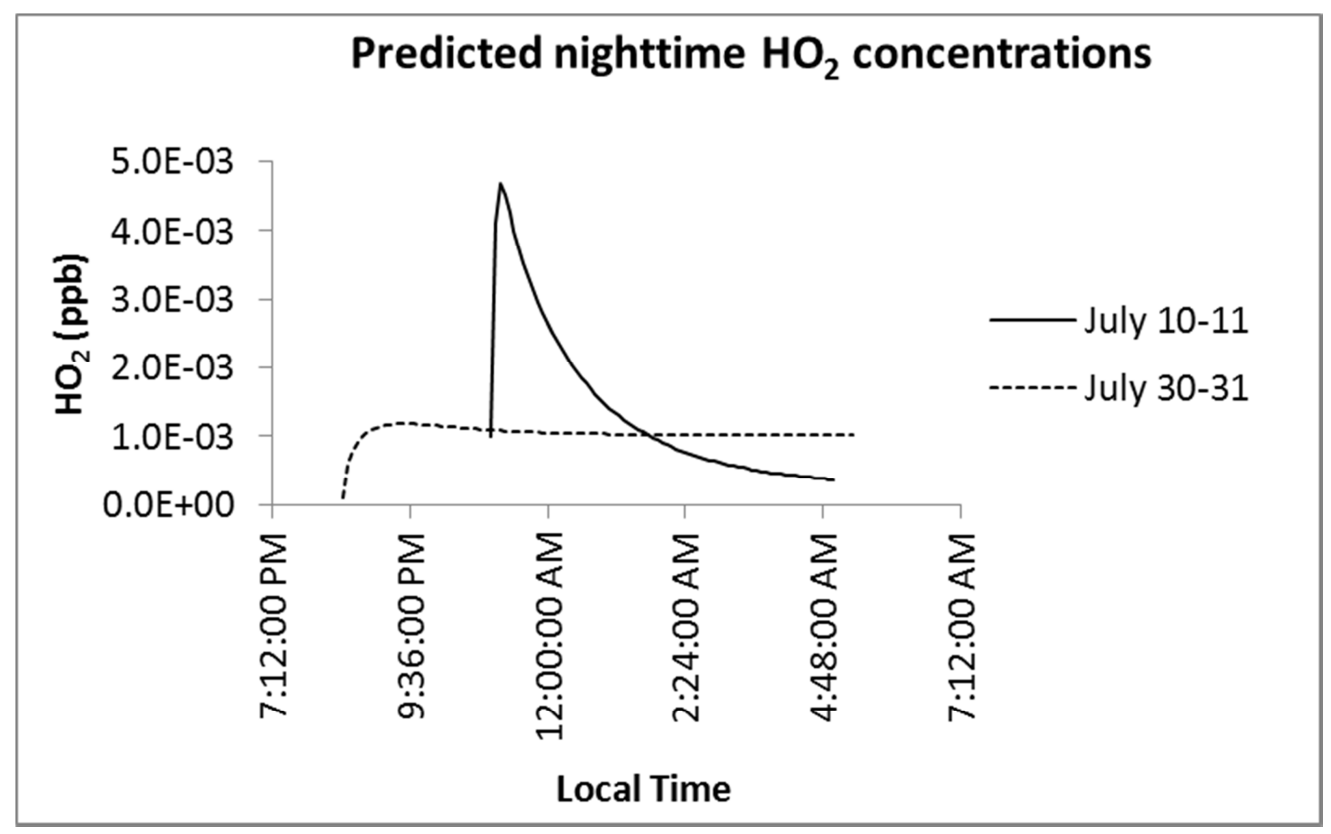




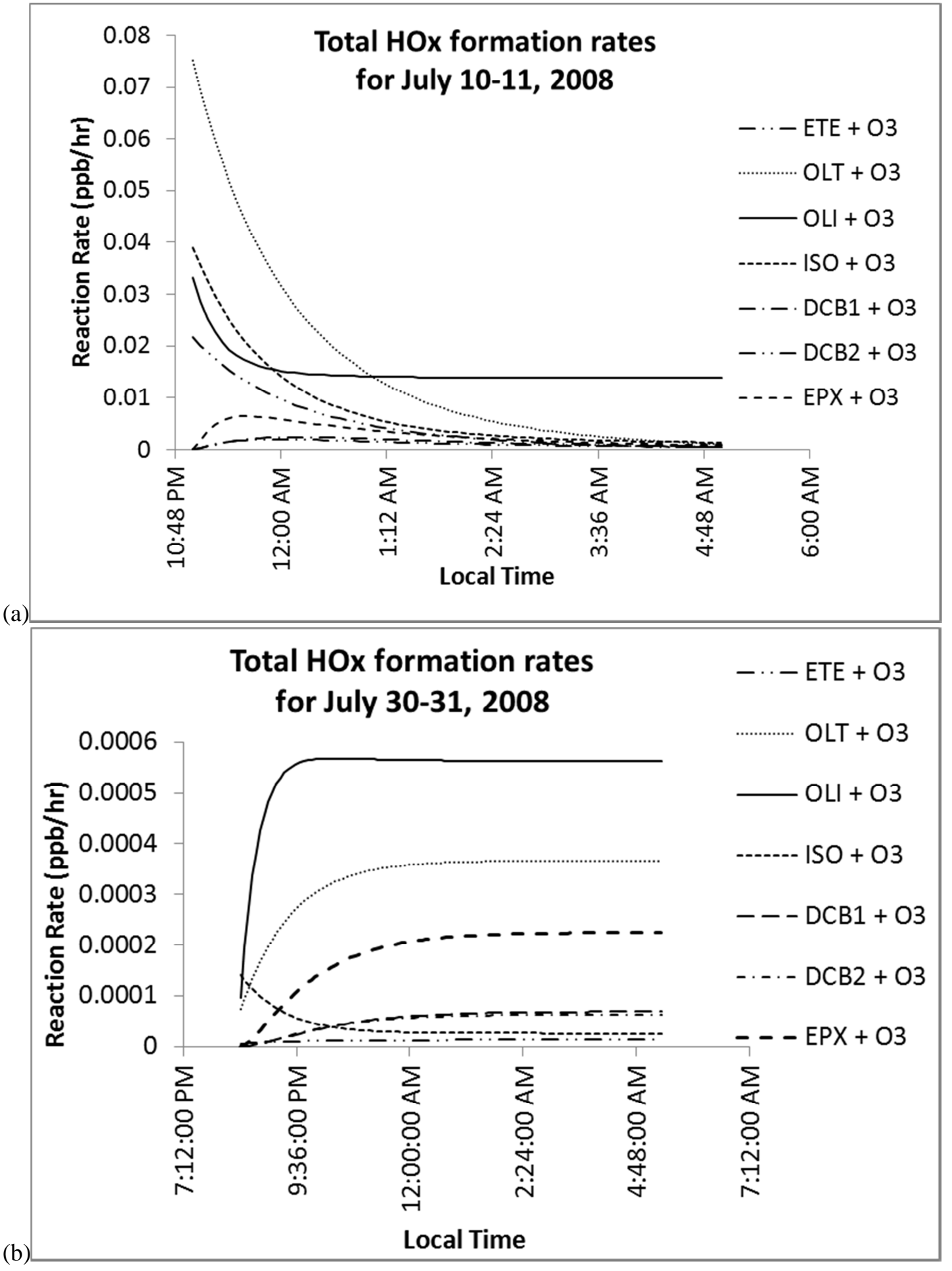




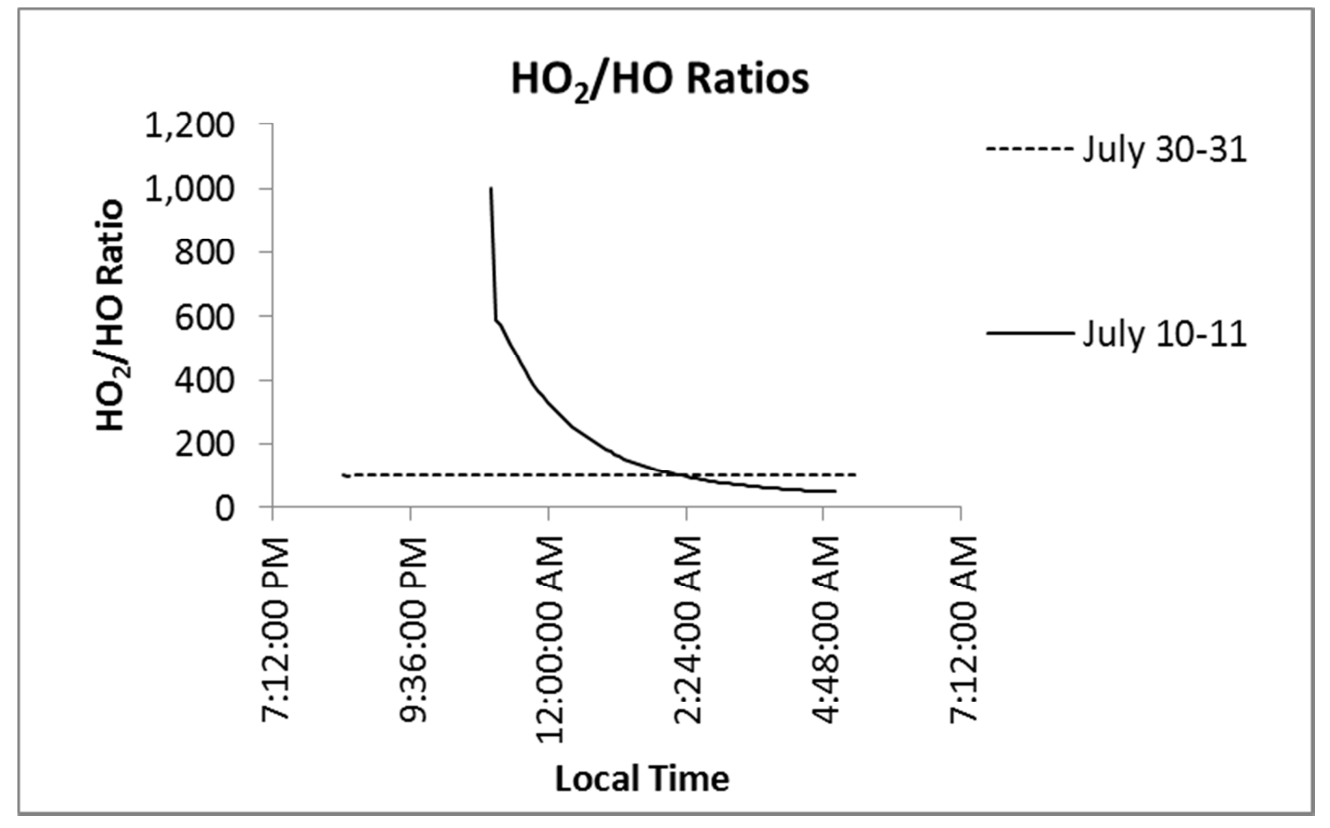




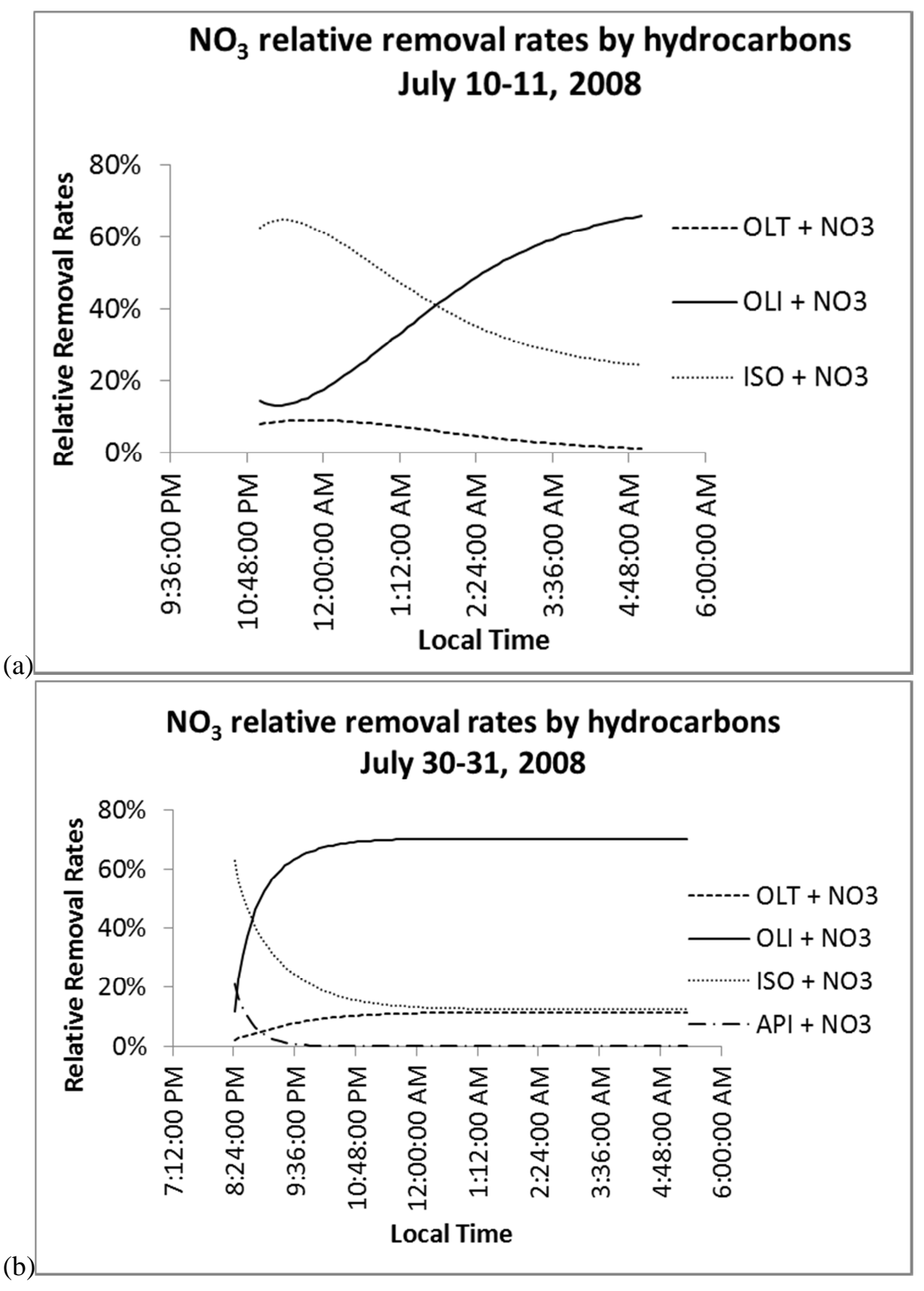




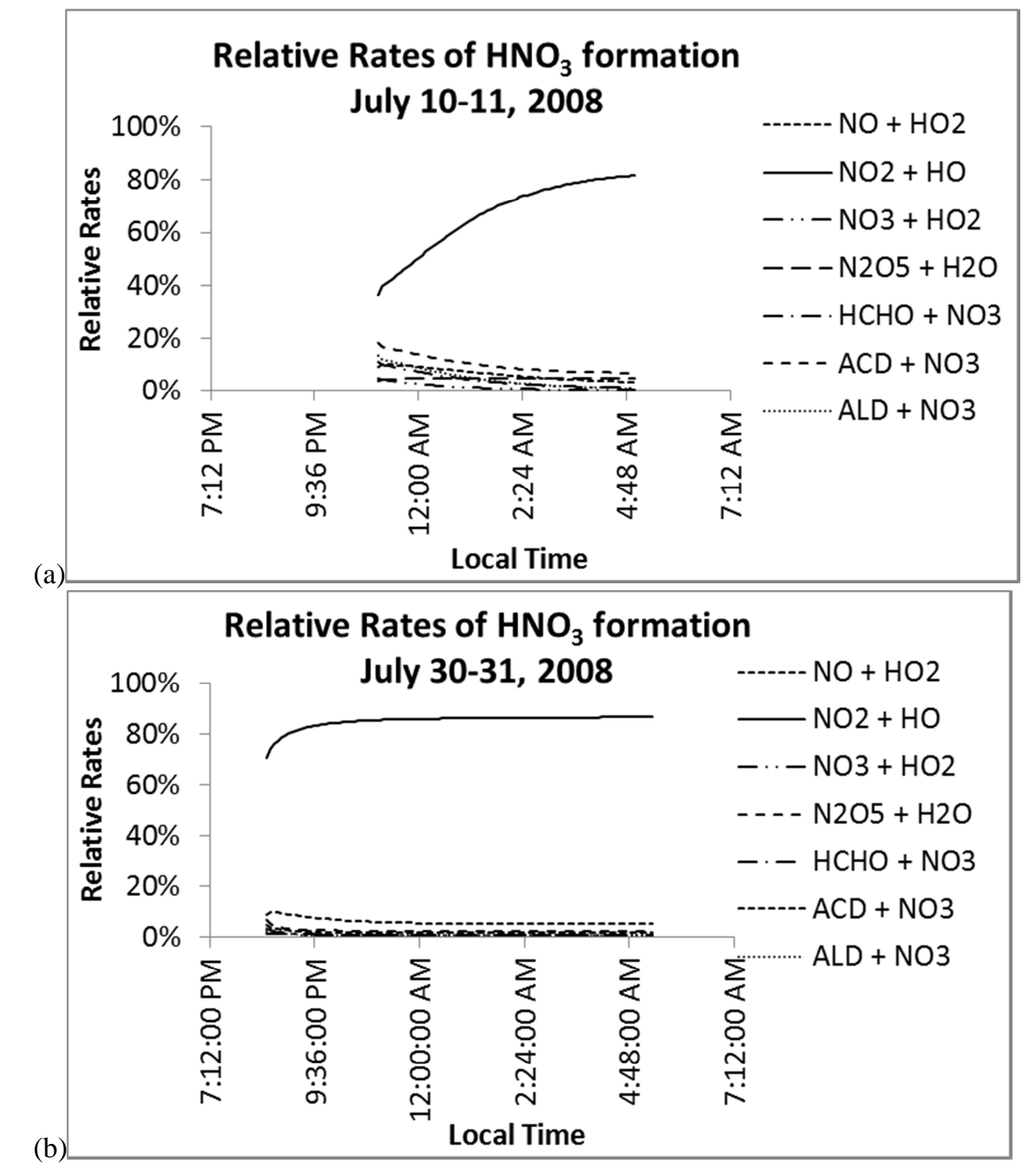

